\title{
Effect of gibberellic acid on berry yield and quality attributes of grapes cv. sultanina
}

Naveeda Anjum ${ }^{1}$, Muhammad Aqeel Feroze ${ }^{1}$, Rizwan Rafique ${ }^{2 *}$ and Monis Hussain Shah ${ }^{3}$

1. Barani Agricultural Research Institute Chakwal-Pakistan

2. Agriculture Department (Extension) Punjab-Pakistan

3. Horticultural Research Institute for Floriculture \& Landscaping Rawalpindi-Pakistan

*Corresponding author's email: rizwanrafiqueao@gmail.com

Citation

Naveeda Anjum, Muhammad Aqeel Feroze, Rizwan Rafique and Monis Hussain Shah. Effect of gibberellic acid on berry yield and quality attributes of grapes cv. sultanina. Pure and Applied Biology. Vol. 9, Issue 2, pp1319-1324. http://dx.doi.org/10.19045/bspab.2020.90137

\begin{tabular}{llll}
\hline \hline Received: 01/11/2019 & Revised: 20/01/2020 & Accepted: 03/02/2020 & Online First: 24/02/2020 \\
\hline
\end{tabular}

\section{Abstract}

Grape is an important horticultural commodity for fresh and processed consumption in the form of fruit and Kishmish (dry grapes). Pakistan have excellent growing environment for different seedless and seeded varieties of grapes. There are a lot of issues of viticulture in Pakistan amongst fruit quality is worth to address. The present study was carried out to observe the effect of Gibberellic acid for better fruit and quality attributes in cv. Sultanina. Gibberellic acid $\left(\mathrm{GA}_{3}\right)$ is one of the most important substances for improving quality of fruit. Foliar applications were applied to access and standardize the optimum dose of GA3 $100 \mathrm{mg} / \mathrm{L}, 200 \mathrm{mg} / \mathrm{L}$ and 300mg/L doses along with control. The quality of the fruit was accessed by observing berry size (mm), 10 berry weight $(\mathrm{g})$, berries per cluster and cluster weight $(\mathrm{g})$, Total Soluble Solids $\left(\right.$ Brix $\left.^{\mathrm{o}}\right)$, titratable acidity (\%). It was observed that application of GA3 significantly improved berry weight, berry size and cluster weight however numbers of berries per cluster were reduced. Similarly, Total Soluble Solids (TSS) was significantly increased with application $200 \mathrm{mg} / \mathrm{L}$ of GA3 while titratable acidity (TA) was decreased in gibberellin treatment as compared to control. The optimum dose for better physio-chemical attributes of berries is $300 \mathrm{mg} / \mathrm{L} \mathrm{of} \mathrm{GA}$.

Keywords: Berry quality; Gibberellic acid; Grapes; Pakistan and Sultanina C

\section{Introduction}

Grape (Vitis vinifera L.) is a famous and economically valuable fruit [1] around the globe. Grapes production was recently calculated about 74.5 million tons from the growing area of 7.12 million hectares [2]. China, USA, Italy, Spain, France, Turkey, Argentina, India and Iran [3] are the leading producer of the grapes. Mostly European grape varieties are cultivated for commercial production in Pakistan [4]. Pakistan stands $57^{\text {th }}$ with an annual production of 66,036 tons around the world. Dry Region such as Cholistan, Thar and plain areas of Pothwar region (Attock, Chakwal, Rawalpindi and Khushab) are excellent for grapes production in Pakistan due to low intensity of rainfall in monsoon season. Grapes production is challenged by lack of standardized production technology, unwanted bunch 
compactness, incidence of fungal diseases and presence of large size of seed in leading table varieties. The seedless varieties are the miracle of nature, however modern processed and table grapes varieties are the result of triploid production through hybridization. The triploid can also be taken through cotyledon as they are triploid in nature. The selflessness can also be the result of epigenetic changes during or prior to seed formation. Gibberellins belong to a group of more than 130 tetracyclic diterpenes and have principal growth-active structures, as $\mathrm{GA}_{1}, \mathrm{GA}_{3}, \mathrm{GA}_{4}$, and $\mathrm{GA}_{7}$. Tetracyclic diterpenoid carboxylic acids possess a 20nor-ent-gibberellane skeleton; a carboxyl group on C-6, a lactone function between C4 and C-10, and a hydroxyl or other functional group at C-3 [5]. Recent studies have established that bioactive GAs are involved in key aspects of plant development, as seed germination, flower induction, fruit and seed development [6]. Berry quality is influenced by both endogenous (e.g. nutritional and hormonal factors) and exogenous factors (e.g. temperature, light and water availability) [7]. Seediness is controlled by endogenous growth promoters [8]. Presence of berry is significantly correlated with endogenous gibberellins [9] and growth retardants. Substances such as 2chloroethyl trimethylammonium chloride (CCC), increase fruit set but reduce berry size and sugar accumulation by inhibiting gibberellins synthesis [10].These substances did not harm plant and environment. Influence of Gibberellins $\left(\mathrm{GA}_{3}\right)$ is observed in tomato and other vegetables for parthenocarpic fruit induction through exogenous application. Gibberellins induce fruit development in unfertilized ovaries. Gibberellins also overcome the suspended growth of dormant pollinated ovaries [11]. The present study is based on results of exogenous application of $\mathrm{GA}_{3}$ for better quality fruit production in Sultanina grapes.

\section{Materials and methods}

The research was conducted at BARI (Barani Agricultural Research Institute, Chakwal). The plants of Sultanina were planted at the distance of $6 \times 10$ feet apart during the year of 2010. The regular field operations were carried out regarding irrigation and fertilizer application. Gibberellic acid foliar spray was applied at full bloom while spray was repeated after a weak. Four treatments include, T1: Control, T2: 100mg/L, T3: 200mg/L and T4: $300 \mathrm{mg} / \mathrm{L}$ and with three replications of each treatment were laid out for application of Gibberellic acid. The research trial was conducted according to the RCBD experimental design with 3 replications and four treatments and means were compared at 5\% level of significance using Statistix 8.1.The berries and clusters were subjected to the following physical and chemical attributes.

\section{Physical and cluster attributes}

Cluster weight (g), number of berries/Cluster, Individual berry weight (g), Individual berry size (cm: through Vernier calipers) were recorded at edible maturity. Thirty clusters were randomly selected at harvest to determine the cluster weight (g), nine clusters were selected for counting number of berries in each cluster, and thirty berries were randomly taken from these clusters from different bunch positions to determine individual berry weight ( $\mathrm{g}$ ).

\section{Biochemical attributes of berries}

The total soluble solids (TSS: Brix $^{\circ}$ ) contents of grape juice were estimated at harvest through Digital (RX 5000, ATAGO, Japan) Refractometer. Determination of titratable acidity TA (\%) was measured through Hortwitz methods [12]. Mathematically, the total titratable acidity (\%) was determined by using the following formula; 
Titratable acidity $(\%)=[(\mathrm{mL} \mathrm{NaOH}$ used $)($ Normality of $\mathrm{NaOH})($ Equillent wt. of tertaric acid $)]$ (Volume of aliquot taken) $\times 100$

\section{Results}

There were three (100, 200 and $300 \mathrm{mg} / \mathrm{L})$ doses for exogenous application of GA3 along with control in addition to control during the period 2016-2018. During the year 2016, significantly higher cluster weight (361g) was observed with the application of $300 \mathrm{mg} / \mathrm{L}$ followed by $322 \mathrm{~g}$ with $200 \mathrm{mg} / \mathrm{L}$ of $\mathrm{GA}_{3}$ application. The same trends regarding berry weight were observed during the study years of $2016(41.16 \mathrm{~g}), 2017(45.80 \mathrm{~g})$ and $2018(49.0 \mathrm{~g})$ respectively in exogenous application of highest dose of $\mathrm{GA}_{3}$ (300mg/L), while lower doses of $200 \mathrm{mg} / \mathrm{L}$ and $100 \mathrm{mg} / \mathrm{L}$ showed lower berry weight as shown in (Table 1). Berry size was significantly higher during the year 2016
$(2.4 \mathrm{~mm}), \quad 2017 \quad(2.96 \mathrm{~mm})$ and 2018 $(2.36 \mathrm{~mm})$ with exogenous application of $\mathrm{GA}_{3}$ highest dose $(300 \mathrm{mg} / \mathrm{L})$ while less berry size was recorded in lower strength of $\mathrm{GA}_{3}$ of $200 \mathrm{mg} / \mathrm{L}, 100 \mathrm{mg} / \mathrm{L}$. The Berries per cluster were significantly less in treatments with $\mathrm{GA}_{3}$ application in all the year. Minimum berry size was found at $300 \mathrm{mg} / \mathrm{L}$ and $200 \mathrm{mg} / \mathrm{L}$ exogenous application of $\mathrm{GA}_{3}$ as compared to control with no $\mathrm{GA}_{3}$ treatment (Table 1).

This may be due to plant mechanism for maintenance of good berry size and weight. Overall application of $\mathrm{GA}_{3}$ improved the berry growth and berry quality traits in comparison with control but it resulted in decreased berries per cluster.

Table 1. Effect of foliar applications of GA3 in cv. Sultanina-C on berry attributes

\begin{tabular}{|c|c|c|c|c|c|}
\hline \multirow{2}{*}{ Treatment } & \multirow{2}{*}{$\mathbf{G A}_{3}$} & \multicolumn{3}{|c|}{ Year } & \multirow{2}{*}{ Mean } \\
\hline & & 2016 & 2017 & 2018 & \\
\hline \multirow{4}{*}{$\begin{array}{c}\text { Cluster } \\
\text { weight }(\mathrm{g})\end{array}$} & Control & $250.3 \mathrm{H}$ & $262.1 \mathrm{G}$ & $218.3 \mathrm{I}$ & $243.6 \mathrm{D}$ \\
\hline & $100 \mathrm{mg} / \mathrm{L}$ & $269.0 \mathrm{G}$ & $287.1 \mathrm{~F}$ & $248.0 \mathrm{H}$ & $268.0 \mathrm{C}$ \\
\hline & $200 \mathrm{mg} / \mathrm{L}$ & $322.0 \mathrm{D}$ & $358.0 \mathrm{BC}$ & $302.6 \mathrm{E}$ & $327.5 \mathrm{~B}$ \\
\hline & $300 \mathrm{mg} / \mathrm{L}$ & $361.6 \mathrm{~B}$ & $389.6 \mathrm{~A}$ & $351.0 \mathrm{C}$ & $370.4 \mathrm{~A}$ \\
\hline \multirow{4}{*}{$\begin{array}{c}10 \text { Berry } \\
\text { weight }(\mathrm{g})\end{array}$} & Control & $27.7 \mathrm{H}$ & $25.2 \mathrm{I}$ & $33.3 \mathrm{~F}$ & $28.7 \mathrm{D}$ \\
\hline & $100 \mathrm{mg} / \mathrm{L}$ & $31.0 \mathrm{G}$ & $31.4 \mathrm{G}$ & $35.1 \mathrm{E}$ & $32.5 \mathrm{C}$ \\
\hline & $200 \mathrm{mg} / \mathrm{L}$ & $36.3 \mathrm{E}$ & $38.1 \mathrm{D}$ & $39.3 \mathrm{D}$ & $37.9 \mathrm{~B}$ \\
\hline & $300 \mathrm{mg} / \mathrm{L}$ & $41.1 \mathrm{C}$ & $45.8 \mathrm{~B}$ & $49.0 \mathrm{~A}$ & $45.3 \mathrm{~A}$ \\
\hline \multirow{4}{*}{$\begin{array}{l}\text { Berry Size } \\
\quad(\mathrm{mm})\end{array}$} & Control & $1.9 \mathrm{E}$ & $1.8 \mathrm{~F}$ & $2.03 \mathrm{D}$ & $1.9 \mathrm{D}$ \\
\hline & $100 \mathrm{mg} / \mathrm{L}$ & $2.0 \mathrm{D}$ & $2.1 \mathrm{D}$ & $2.0 \mathrm{D}$ & $2.0 \mathrm{C}$ \\
\hline & $200 \mathrm{mg} / \mathrm{L}$ & $2.3 \mathrm{C}$ & $2.4 \mathrm{~B}$ & $2.1 \mathrm{D}$ & $2.2 \mathrm{~B}$ \\
\hline & $300 \mathrm{mg} / \mathrm{L}$ & $2.4 \mathrm{~B}$ & $2.9 \mathrm{~A}$ & $2.3 \mathrm{BC}$ & $2.5 \mathrm{~A}$ \\
\hline \multirow{4}{*}{$\begin{array}{l}\text { Berries/ } \\
\text { Cluster }\end{array}$} & Control & $85.9 \mathrm{D}$ & 86.1D & $64.0 \mathrm{~F}$ & $78.6 \mathrm{D}$ \\
\hline & $100 \mathrm{mg} / \mathrm{L}$ & $91.1 \mathrm{C}$ & $96.4 \mathrm{~B}$ & $66.1 \mathrm{~F}$ & $84.5 \mathrm{C}$ \\
\hline & $200 \mathrm{mg} / \mathrm{L}$ & $102.6 \mathrm{~A}$ & $104.5 \mathrm{~A}$ & $82.6 \mathrm{D}$ & $96.6 \mathrm{~A}$ \\
\hline & $300 \mathrm{mg} / \mathrm{L}$ & $94.7 \mathrm{BC}$ & 93.0BC & $75.0 \mathrm{E}$ & $87.5 \mathrm{~B}$ \\
\hline
\end{tabular}

Effect of Different Concentration of $\mathrm{GA}_{3}$ on Berry Biochemical Properties

The results showed that TSS (Brix) is significantly higher in exogenous application of $\mathrm{GA}_{3}(200 \mathrm{mg} / \mathrm{L})$ during 2016 (18.63), 2017 (18.76) and 2018 (20.60) while it is lowest in control 16.36 and 17.06 with $300 \mathrm{mg} / \mathrm{L}$ of $\mathrm{GA}_{3}$ (Table 2). 
Titratable Acidity (TA) was less during 2016 (0.26), $2017 \quad(0.26)$ with exogenous application of $\mathrm{GA}_{3}(200 \mathrm{mg} / \mathrm{L})$ while in all doses it was significantly higher as shown in (Table 2). Hence, 200mg/L application reduced TA while highest TA was observed with control although differences of TA vary during the year which may indicate towards strong environmental factors during these periods.

Table 2. Effect of foliar application of GA3 on cv. Sultanina-C berry quality

\begin{tabular}{|c|c|c|c|c|c|}
\hline \multirow{2}{*}{ Attributes } & \multirow{2}{*}{ Treatment } & \multicolumn{3}{|c|}{ Year } & \multirow{2}{*}{ Mean } \\
\cline { 2 - 5 } & & $\mathbf{2 0 1 6}$ & $\mathbf{2 0 1 7}$ & $\mathbf{2 0 1 8}$ & $17.1 \mathrm{C}$ \\
\hline \multirow{3}{*}{$\begin{array}{c}\text { TSS } \\
\left(\text { Brix }^{\circ}\right)\end{array}$} & Control & $16.3 \mathrm{~F}$ & $17.2 \mathrm{DE}$ & $17.7 \mathrm{CD}$ & $17.6 \mathrm{~B}$ \\
\cline { 2 - 6 } & $100 \mathrm{mg} / \mathrm{L}$ & $17.5 \mathrm{CD}$ & $16.9 \mathrm{EF}$ & $18.3 \mathrm{BC}$ & $19.3 \mathrm{~A}$ \\
\cline { 2 - 6 } & $200 \mathrm{mg} / \mathrm{L}$ & $18.6 \mathrm{~B}$ & $18.7 \mathrm{~B}$ & $20.6 \mathrm{~A}$ & $17.4 \mathrm{BC}$ \\
\cline { 2 - 6 } & $300 \mathrm{mg} / \mathrm{L}$ & $17.0 \mathrm{DEF}$ & $16.4 \mathrm{~F}$ & $18.9 \mathrm{~B}$ & $0.35 \mathrm{~A}$ \\
\hline \multirow{3}{*}{$\begin{array}{c}\text { Titratable } \\
\text { Acidity } \\
(\%)\end{array}$} & Control & $0.35 \mathrm{~B}$ & $0.33 \mathrm{BC}$ & $0.37 \mathrm{~A}$ & $0.33 \mathrm{~B}$ \\
\cline { 2 - 6 } & $100 \mathrm{mg} / \mathrm{L}$ & $0.30 \mathrm{D}$ & $0.31 \mathrm{CD}$ & $0.38 \mathrm{~A}$ & $0.31 \mathrm{C}$ \\
\cline { 2 - 6 } & $200 \mathrm{mg} / \mathrm{L}$ & $0.26 \mathrm{E}$ & $0.26 \mathrm{E}$ & $0.38 \mathrm{~A}$ & $0.30 \mathrm{C}$ \\
\cline { 2 - 6 } & $300 \mathrm{mg} / \mathrm{L}$ & $0.32 \mathrm{BC}$ & $0.32 \mathrm{CD}$ & $0.31 \mathrm{CD}$ & \\
\hline
\end{tabular}

\section{Discussion}

Application of $\mathrm{GA}_{3}$ increases number of berries or bunch weight through application of single dose of $320 \mathrm{mg} / \mathrm{L}$. Bioactive Gibberellins are involved in several important aspects of plant development, flower induction, including seed germination, fruit and seed development [6]. The results of present study are parallel [13] as recommended $650 \mathrm{mg} / \mathrm{L}$ of GA3 for cluster weight in cv. Sultanina. However general recommendation for better yield in $\mathrm{cv}$. Sultanina is $100 \mathrm{mg} / \mathrm{L}$ for better cluster size and berry weight [14]. However application stage of $\mathrm{GA}_{3}$ is critical for better results and berry development as application on cell enlargement stage, increases berry weight in seedless varieties. This effect is showed due to an increase in total sugars contents which increases total water content. However sweetness in seeded varieties is observed more due to appropriate presence of sink while seedless varieties did not have a suitable sink for good sugar contents development [15]. Sugars accumulation is related to ripening for a better berry quality. Sugars bear osmotic driving force for cellular expansion [16] and modulation of gene expression [17] by signaling mechanisms [16]. Application of GA3 reduces $80 \%$ of bloom on plants. This reduction is similar to that reported for GA3- mediated berry thinning on other seedless cultivars the rest of the berries gain weight and ultimately produces larger size of berries as compared with those without GA3 spray. Effect of GA3 has not been observed on altering or betterment of $\mathrm{pH}$ and of fruit juice. The effects of GA3 on firmness, size, and soluble solids content is observed little information is available on the influence of GA on postharvest qualities of fruit or sensory attributes after storage [18]. Gibberellic treatment at higher concentration appears to reduce the incidence of sweetness in fruits. Gibberellic acid spray reduces fruit decay, which may be related to changes in cuticle integrity and micro-crack formation. Furthermore, Spray GA3, an inhibitor of GA biosynthesis, increased fruit cuticle the thickness and fruit firmness. Although, the gibberellin application reduced the berry per cluster but overall quality traits are increased as highlighted in the present study. 


\section{Conclusion}

Application of growth regulators especially $\mathrm{GA}_{3}$ can positively influence fruit quality of grapes especially in seedless varieties. Standardization of optimum dose for exogenous application of $\mathrm{GA}_{3}$ for common farmers is a key for early and high quality berry harvest. However there are number of varieties of commercial importance which have been cultivated for commercial purpose and there is a need to further study the physiological and biochemical basis of gibberellin. Results also indicate some sort of environmental interactions with $\mathrm{GA}_{3}$ applications through seasonal variability which is gap to study in future research. Our results demonstrate optimum dose for best yield and quality attributes of berries is $200 \mathrm{mg} / \mathrm{L}$ to $300 \mathrm{mg} / \mathrm{L}$ of $\mathrm{GA}_{3}$ application.

\section{Authors' contributions}

Conceived and designed the experiments: N Anjum, MA Feroz \& R Rafique, Performed the experiments: N Anjum \& MA Feroz, Analyzed the data: R Rafique, $\mathrm{MH}$ Shah, Contributed materials/ analysis/ tools: N Anjum \& MA Feroz, Wrote the paper: N Anjum, MA Feroz, R Rafique \& MH Shah.

\section{Acknowledgement}

The authors are thankful to Barani Agricultural Research Institute, Chakwal for financial support to research.

\section{References}

1. Ruel JJ \& Walker MA (2006). Resistance to Pierce's disease in Muscadinia rotundifolia and other native grape species. Ame J Enol \& Viti 57: 158 -165 .

2. FAO (2014). Crops. FAOSTAT. Food and Agriculture Organization of the United Nations. Available at: http://www.fao.org/ Accessed on 10-082018.

3. FAO (2017). Crops. FAOSTAT. Food and Agriculture Organization of the United Nations. Available at: http://www.fao.org/ Accessed on 11-012019.

4. Shaheen K, Sidra A, Chandni K \& Tika K (2017). An Allometric Growth Estimation of Grapes (Vitis vinifera L.) from High Mountainous Region of Gilgit-Baltistan. Pak J Chem Bio \& Envir Eng 2(4): 34 -37.

5. Davies PJ (2004). Plant hormones: biosynthesis, signal transduction, action. Kluwer Academic Publishers, Dordrecht.

6. Hedden P \& Kamiya Y (1997). Gibberellin biosynthesis: enzymes, genes and their regulation. Ann Rev Plant Physiol \& Plant Mol Biol 48: 431460.

7. Ollat N, Diakou-verdin P, Carde JP, Barrieu F, Gaudillere JP \& Moing A (2002). Grape berry development: a review. J Inter Sci Vig and Vine 36: 109131.

8. May P (2000). From bud to berry, with especial reference to inflorescence and bunch morphology in Vitisvinifera L. Aust J Grap Wine Res 6: 82-98.

9. Gokturk N \& Harmankaya N (2005). Changes in endogenous hormone levels during the ripening of grape cultivars having different berry set mechanisms. Turk J Agric Forest 29: 205-210.

10. Looney NE (1981). Some growth regulator and cluster thinning effects on berry set and size, berry quality and annual productivity of the 'Chauna'grapes. Viticul 20: 22-35.

11. Magdalena K, Agnieszka N, Piotr B \& Kamila K (2017). Effect of gibberellic acid concentration and number of treatments on yield components of "Einset Seedless" grapevine cultivar. Hortic Sci 44(4): 195-200.

12. Hortwitz W (1960). Official and tentative methods of analysis. Associate of the official Agricultural Chemis, Washington, D.C., USA, pp 320-341. 
13. Korkas E, Nerantzis E, Kourtidou-tymba P \& Banilas G (1999). The effect of gibberellic acid application at different phenological growth stages on yield and quality parameters of 'Sultanina' table grapes (Vitis vinifera L.) in Greece. Part I. At development of flower cluster and at fruit set bloom time. Viticul Enol Sci 54: 44-53.

14. Perez FJ, Viani C \& Retamales J (2000). Bioactive gibberellins in seeded and seedless grapes: identification and changes in content during berry development. Amer J Enol and Viticul 51: 315-318.

15. Zhenming $\mathrm{N}$, Xuefeng $\mathrm{X}, \mathrm{Yi} \mathrm{W}$, Tianzhong L, Jin K \& Zhenhai H (2008). Effects of leaf-applied potassium, gibberellin and source-sink ratio on potassium absorption and distribution in grape fruits. Scientia Hort 115:164-167.

16. Lalonde S, Boles E, Hellmann H, Barker L, Patrick JW, Former WB \& Ward JM (1999). The dual function of sugars carriers: transport and sugar sensing. Plant Cell 11: 707-726.

17. Koch KE (1996). Carbohydrate modulated gene expression in plants. Ann Rev Plant Physiol \& Plant Mol Biol 47: 509-540.

18. Horvitz S, Camelo LP, Yommi AF \& Godoy A (2003). Application of gibberellic acid to 'Sweetheart' sweet cherries: effects on fruit quality at harvest and during cold storage. Acta Hort 628: 311-316. 